\section{Isolation of a candidate gene for Norrie disease by positional cloning}

W. Berger, A. Meindl, T. J. R. van de Pol, F. P. M. Cremers, H. H. Ropers, C. Döerner, A. Monaco, A. A. B. Bergen, R. Lebo, M. Warburgh, L. Zergollern, B. Lorenz, A. Gal, E. M. Bleeker-Wagemakers \& T. Meitinger

Nature Genetics 1, 199-203 (1992)

The following revised versions of Figs 2,3,5 and 6 should have appeared in this paper.

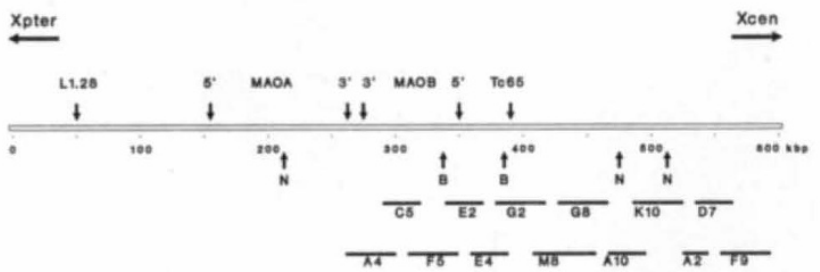

\begin{tabular}{l}
\hline 3162 \\
\hline 289
\end{tabular}

Fig. 1 Overlapping cosmid clones (dark bars) spanning the proximal half of YAC1 which encompasses the ND gene as well as two submicroscopic deletions (nos 3152 and 289). $5^{\prime}$ and $3^{\prime}$ ends of the MAO genes, the locations of marker sequences L1.28 (DXS7) and Tc65, as well as $B S S H I I(B)$ and $\operatorname{Notl}(N)$ restriction sites are indicated by arrows.

Fig. 3 The ND gene region as defined by microdeletions. The location of cosmids (dark bars) and EcoR restriction sites (arrows) are indicated above. Genomic fragments hybridizing to cDNA C2 are underlined.
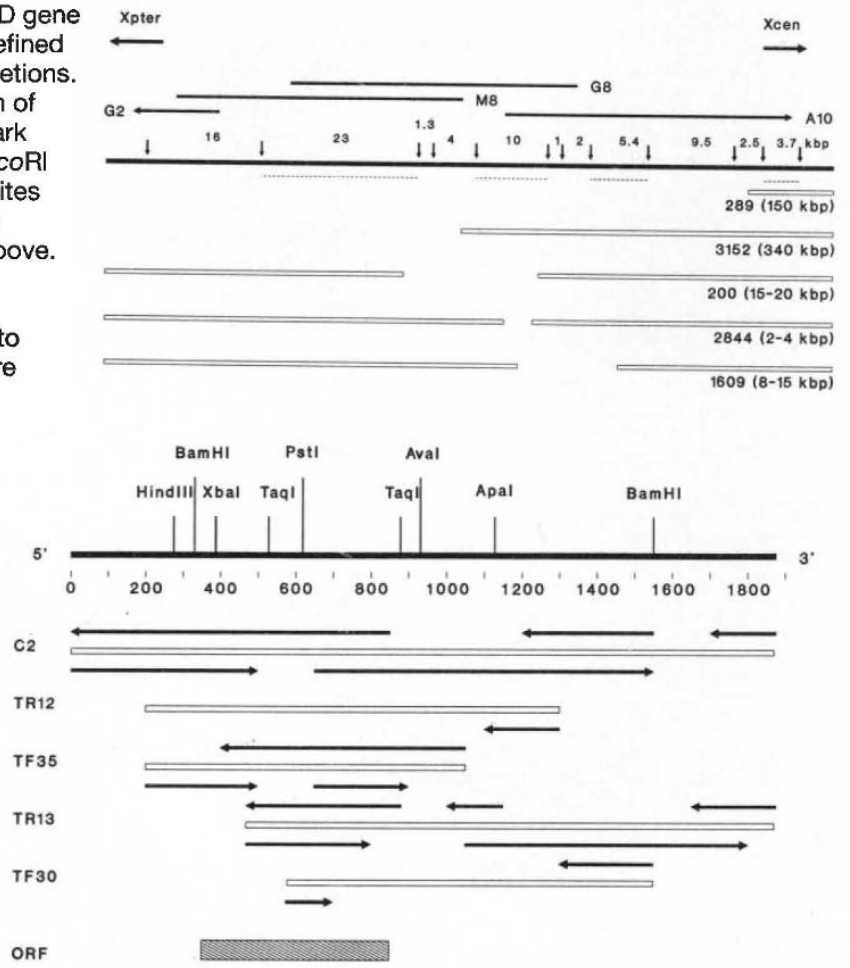

Fig. 5 Overlapping cDNA clones (open bars) spanning $1.9 \mathrm{~kb}$ of the putative ND gene, which were isolated from fetal (C2) and adult retinal libraries (TR12, TR13), and from a fetal brain library (TF30, TF35). Sequenced segments are indicated by arrows, and the open reading frame given as shaded box.

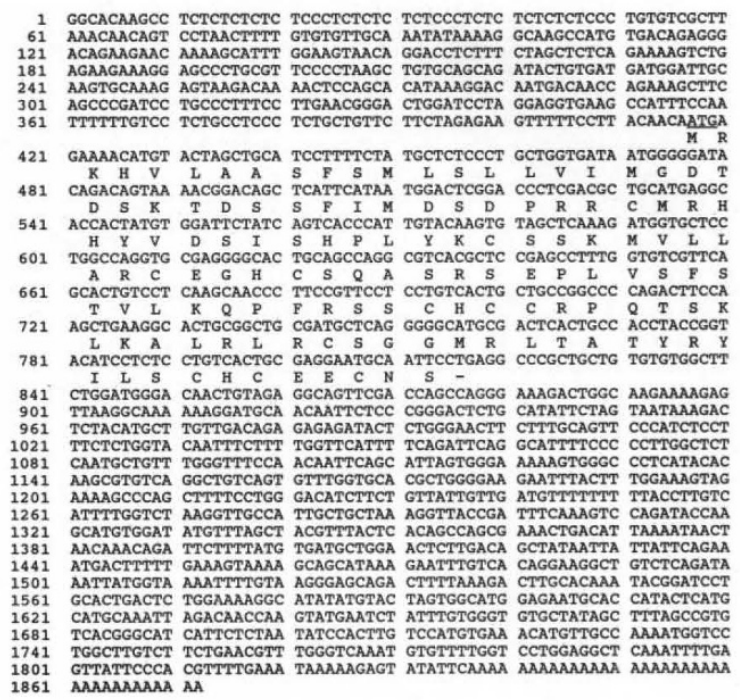

Fig. 6 Nucleotide sequence (EMBL accession number X65724) of the consensus CDNA, and deduced amino acid sequence starting with the putative translation initiation codon at position 417 .

\section{The peripheral myelin protein gene PMP-22 is contained within the Charcot-Marie-Tooth disease type 1A duplication}

V. Timmerman, E. Nelis, W. Van Hul, B. W.

Nieuwenhuijsen, K. L. Chen, S. Wang, K. B.

Othman, B. Cullen, R. J. Leach, C. O. Hanemann, P. De Jonghe, P. Raeymaekers, G.-J. B. van Ommen, J.J. Martin, H. W. Müller, J. M. Vance, K. H. Fischbeck \& C. Van Broeckhoven Nature Genetics 1, 171-175 (1992)

In Fig. 1 , part $b$ should have been represented by the figure reproduced below.

$\begin{array}{llllllll}1 & 2 & 3 & 4 & 5 & 6 & 7 & 8\end{array}$

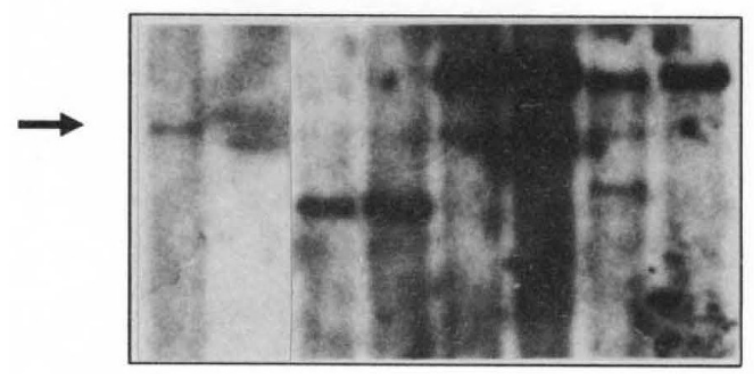

Fig. 1 Cell hybrid mapping of PMP-22 to human chromosome 17p11.2. b, Southern blot of Taql digested DNA hybridized with pmp-22 cDNA CD25: lane 1 human; lane 2 hamster; lanes 3-4 somatic cell hybrid FTH(17)L4; lanes 5-7 somatic cell hybrids GM10889, GM10501 and GM10331, lane 8 mouse B82. The $5.5 \mathrm{~kb}$ human Taql fragment is indicated by the arrow. The lower weight Taql band seen in FHTB(17)L4 corresponds to the hybridization signal obtained with Taql digested DNA from the parent rat line FT02B of FTHB9(17)L4 with the PMP-22 CDNA CD25. 